\section{Hypersensitivity pneumonitis induced by a smut fungus Ustilago esculenta}

Kazuko Yoshida, Moritaka Suga, Hisato Yamasaki, Kenji Nakamura, Toyozo Sato, Makoto Kakishima, James A Dosman, Masayuki Ando

\section{Abstract \\ A case of hypersensitivity pneumonitis caused by a smut fungus Ustilago escu- lenta is presented. \\ (Thorax 1996;51:650-651)}

Keywords: hypersensitivity pneumonitis, smut, Ustilago esculenta.

Ustilago is the most prevalent smut fungus in grain. ${ }^{1-4}$ It is listed as an aeroallergen associated with bronchial asthma, but not with hypersensitivity pneumonitis. ${ }^{4-7}$ This is the first reported case of hypersensitivity pneumonitis to be caused by Ustilago esculenta. We present this case in order to raise the possibility of Ustilago induced hypersensitivity pneumonitis among grain workers and farmers.

\section{Case report}

A 40 year old woman engaged in Japanese traditional handicrafts developed increasing dyspnoea, cough, and fever. She recovered completely after two weeks away from work but developed the same symptoms again at midnight on the day she returned to work.

The results of physical examination, routine laboratory studies, and pulmonary function tests were normal. A chest radiograph and high resolution computed tomographic scan showed diffuse bilateral fine nodular shadows without hilar adenopathy. Cultures for microorganisms including mycobacteria from sputum, bronchoalveolar lavage fluid, and gastric juice showed normal flora or were negative. The bronchoalveolar lavage was performed a week after the last exposure by methods described previously. ${ }^{7}$ Of the $150 \mathrm{ml}$ saline injected, $100 \mathrm{ml}$ of bronchoalveolar fluid was recovered. The total cell yield was $78.4 \times 10^{6}\left(87.1 \times 10^{4} /\right.$ $\mathrm{ml}$ ), and the differential cell count was $54.7 \%$ lymphocytes, $41.5 \%$ pulmonary alveolar macrophages, $3.5 \%$ polymorphonuclear leucocytes, and $0.3 \%$ eosinophils with a CD4/CD8 ratio of $1 \cdot 61$. A transbronchial lung biopsy specimen revealed granulomatous alveolitis.
The causative antigen suspected was smut spores in her work place. She sprinkled these spores on lacquered wares and blew the excess off, producing a rusty colour. Macroscopically, the spores were brown and powdery, and microscopically they were single, globular or ellipsoid, measuring $5 \cdot 0-10 \cdot 2 \times 4.2-6.5 \mu \mathrm{m}$. The smut teliospores were identified by morphometric examination as Ustilago esculenta.

Several procedures were conducted to prove that the spores of $U$ esculenta were the causative antigen.

INDIRECT FLUORESCENT ANTIBODY (IFA) TEST The method of Vogel, slightly modified, was performed as previously reported. ${ }^{89}$ Spores of $U$ esculenta and dust from the work place of the patient were tested with the patient's serum and with control serum samples. The spores were only reactive to the patient's serum among the dusts tested and showed an IFA titre of 1:512, while control serum samples showed less than $1: 8$.

GEL DOUBLE DIFFUSION TEST

The method of Gerber and Jones, slightly modified, was performed as previously reported. ${ }^{89}$ Antigen was extracted from the teliospores of $U$ esculenta with sodium bicarbonate buffered saline by a modified version of Santilli's method. ${ }^{6}$ The serum of the patient showed dense precipitins against the extracted antigen $(10 \mathrm{mg}$ dry weight $/ \mathrm{ml})$ and a faint precipitin against only Aspergillus niger from among common hypersensitivity pneumonitis related and Aspergillus related antigens (Hollister-Steir, Spokane, Washington).

LYMPHOCYTE PROLIFERATIVE RESPONSE TEST FOR PERIPHERAL BLOOD CELLS

Cellular incorporation of $\left[{ }^{3} \mathrm{H}\right]$ thymidine was determined by the method of Moore and coworkers ${ }^{9}$ and expressed as a stimulating index: the mean cpm of wells containing $1 \times 10^{5} \mathrm{lym}-$ phocytes (viability $98 \%$ ) and antigen or mitogen divided by the mean cpm of wells without stimulant. Lymphoproliferative responses to the extracted antigen were observed in a dose dependent manner. The maximum net stimulation and stimulation index value were $5443 \mathrm{cpm}$ and $23 \cdot 8$, respectively, at $0.8 \mu \mathrm{g} / \mathrm{ml}$ concentration. No significant response was observed in control cells.

SKIN TEST

Skin reaction to the extracted antigen was made by intradermal injection with $0.02 \mathrm{ml}$ of a solution $(0.1 \mathrm{mg} / \mathrm{ml})$ and was read during the 

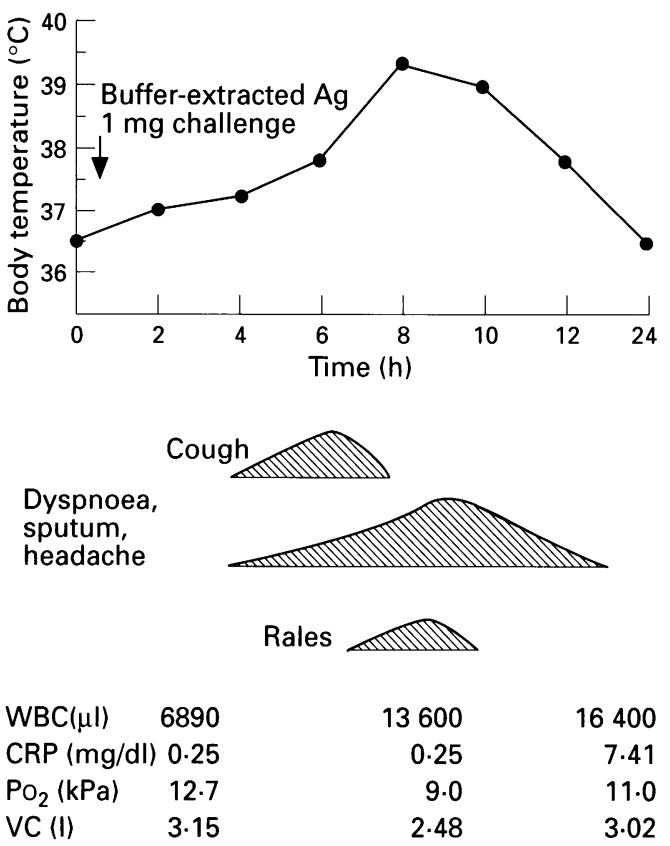

Results of inhalation challenge test with $U$ esculenta performed on the patient using $1 \mathrm{mg}$ of buffer extracted antigen inhaled through an ultrasonic nebuliser. The same provocation test did not show any effect on a healthy control subject.

Published reports of smut-related allergic respiratory diseases

\begin{tabular}{|c|c|c|c|c|}
\hline Year & Country & $\begin{array}{l}\text { No of } \\
\text { patients }\end{array}$ & Symptoms & Antigens \\
\hline 1937 & USA & 1 & Asthma & \multirow{2}{*}{$\begin{array}{l}\text { Ustilago zeae (=maydis), } \\
\text { Tilletia levis }(=\text { foetida) etc } \\
U \text { tritici, } U \text { zeae, } U \text { avnae, } \\
T \text { tritici, } T \text { levis, etc. }\end{array}$} \\
\hline 1939 & USA & 13 & $\begin{array}{l}5 \text { asthma, } 6 \text { hayfever, } \\
\text { and } 2 \text { hayfever with } \\
\text { asthma }\end{array}$ & \\
\hline 1940 & USA & 103 & Asthma & \multirow{3}{*}{$\begin{array}{l}T \text { tritici, } T \text { levis, } U \text { zeae } \\
\text { Sphacelotheca sorghi } \\
T \text { tritici, T levis, } U \text { zeae etc }\end{array}$} \\
\hline 1940 & USA & 34 & Asthma and/or hayfever & \\
\hline 1940 & USA & 19 & $\begin{array}{l}17 \text { asthma, } 2 \text { nasal } \\
\text { allergy }\end{array}$ & \\
\hline 1941 & Spain & 2 & Asthma & $T$ caries, $T$ foetida \\
\hline 1952 & Brazil & 1 & Asthma & $U$ tritici \\
\hline 1957 & France & 5 & Asthma & $U$ maydis \\
\hline 1965 & India & ? & Respiratory troubles & $U$ virens \\
\hline 1968 & Japan & 1 & Asthma & U esculenta? \\
\hline 1979 & Japan & 2 & $\begin{array}{l}\text { Hypersensitivity } \\
\text { pneumonitis }\end{array}$ & N.I. \\
\hline
\end{tabular}

$\mathrm{NI}=$ not identified. The antigen was not identified but the authors suspected $U$ esculenta to be the causative antigen in these cases.

Details of the references are available from the authors on request.

next 48 hours. The patient showed immediate and Arthus-type reactions to the antigen but two healthy control subjects did not show any reaction.

\section{INHALATION CHALLENGE TEST}

Ten $\mathrm{ml}$ of the extracted antigen $(0.1 \mathrm{mg} / \mathrm{ml})$ were inhaled through an ultrasonic nebuliser (Omuron, Japan). Symptoms, signs, and laboratory findings were recorded during the next 48 hours. Symptoms and signs were reproduced five hours later with maximum effect nine hours later. Laboratory findings also worsened as shown in the figure. A healthy control subject who had an identical test did not show any abnormality.

The patient's symptoms have not recurred since moving to alternative employment.

\section{Discussion}

We have shown the smut fungus $U$ esculenta to be an aetiological antigen of hypersensitivity pneumonitis. The patient reacted to the antigen and did not show any precipitins to common hypersensitivity pneumonitis related antigens tested. These results agree with findings utilising an animal model where spores of basidiomycetes (including smuts) possessed antigens which were not cross reactive with those of certain fungi imperfecti. ${ }^{10}$

$U$ esculenta is distributed widely throughout Asia, and is parasitic on Manchurian wild rice (Zizania latifolia). In Japan the pure spores have been used as paint in the traditional lacquer industry. Hypersensitivity pneumonitis in millers who process wild rice that is infected by $U$ esculenta has also been reported but the antigen was not defined as inhalation challenge was carried out using the whole flour (table).

Smuts were listed as provocative antigens in bronchial asthma. ${ }^{4-7}$ Recently, Marx reported that the frequency of a positive skin test or RAST to grain smut was significantly higher $(11 \cdot 2 \%)$ among farming cases than controls $(0 \%)$ in Wisconsin. ${ }^{7}$

At present, smuts are not as common in advanced countries as they used to be because of the development of fungicides and smutresistant grains. However, Ustilago is still predominant in grain dust or among atmospheric spores. ${ }^{1-3}$ Our observation of the dust from Saskatchewan grain elevators revealed that it still contained highly immunoreactive smut spores (unpublished data).

The writers wish to thank Dr Yasuhiko Nakagawa for notice of the patient, Dr Toshihiro Kaijwara, Director General of the Japan Plant Protection Association for the advice about smut fungi, Dr Miho Moriyama and Mr Manning Luo for their assistance, and the members of Centre for Agricultural Medicine assistance, and the memt
for their cooperation.

1 Chan-Yeung M, Enarson DA, Kennedy SM. The impact of grain dust on respiratory health. Am Rev Respir Dis 1992;145:476-87.

2 Lacey J. The microflora of grain dusts. In: Dosman JA, Cotton DJ, eds. Occupational pulmonary disease. Focus on grain dust and health. New York: Academic Press, 1980: grain dust

3 Cosentino S, Pisano PL, Fadda ME, Palmas F. Pollen and mold allergy: aerobiologic survey in the atmosphere of Cagliari, Italy (1986-1988). Ann Allergy 1990;65:393400

4 Al-Doory Y, Domson JF. Mould allergy. Philadelphia: Lea \& Febiger, 1984.

5 Fischer GW, Holton CS. Effects of smuts on man and animals. In: Biology and control of the smut fungi. New York: The Ronald Press Company, 1957:377-92.

6 Santilli J Jr, Rockwell WJ, Collins RP. Individual patterns of immediate skin reactivity to mold extracts. Ann Allergy 1990;65:454-8.

7 Marx JJ Jr, Twiggs JT, Ault BJ, Merchant JA, Fernandez$\mathrm{Caldas} \mathrm{E}$. Inhaled aeroallergen and storage mite reactivity in a Wisconsin farmer: nested case-control study. Am Rev in a Wisconsin farmer: nested

8 Yoshida K, Ando M, Sakata T, Araki S. Environmental mycological studies on the causative agent of summertype hypersensitivity pneumonitis. $\mathcal{f}$ Allergy Clin Immunol 1988;81:475-83.

9 Ando M, Sakata T, Yoshida K, Yamasaki H, Araki S, Onoue K, Shinoda T. Serotype-related antigen of Trichosporon cutaneum in the induction of summer-type hypersensitivity pneumonitis: correlation between serotype of inhalation challenge-positive antigen and that of the isolates from patients' homes. F Allergy Clin Immunol 1990;85:36-44.

10 Lopez M, Salvaggio J, Butcher B. Allergenicity and immunogenicity of Basidiomycetes. $\mathcal{F}$ Allergy Clin Immunol 1976;57:480-8 